\title{
SISTEM PEMBINAAN LUAR LEMBAGA BAGI NARAPIDANA YANG MERATA DAN BERKEADILAN BERPERSPEKTIF PADA TUJUAN PEMASYARAKATAN
}

\author{
Noeke Sri Wardhani, Sri Hartati, Helda Rahmasari ${ }^{1}$
}

\begin{abstract}
The purpose of the first year research is to explain the implementation of Pembebasan Bersyarat (PB), Cuti Menjelang Bebas (CMB) and Cuti Bersyarat $(C B)$ to indentify the obstacles of the implementation and to arrange the model concept of outside institution development for the prisoners in regard to the implementation of $P B, C M B$ and $C B$ that is fair, equitable and based on the perspective of correctional purpose. In the second year, the purpose of the researh is to carry out workshop in regards to socialized the model concept of outside institution development for the prisoners in regard to the implementation of $P B, C M B$ and $C B$, that is fair, equitable and based on the perspective of correctional purpose. The result of the first year research will be cross-checked with the response paper from the Regional Office of Ministry of Law and Human Rights in Bengkulu, Correctional Institution in Bengkulu (Lembaga Pemasyarakatan Bengkulu and Balai Pemasyarakatan (Bapas) Bengkulu. Based on the workshop, we will give input to the Directorate General of Correctional System at the Ministry of Law and Human Rights (Dirjen Pemasyarakatan) to make the policy of outside institution development. This research is a descriptive-explanatory research and use Sociology of Law as its approach. The data was be collected by questionnaire, in-depth interview, observation and literature study which identifies Penelitian Kemasyarakatan (Litmas) and the document of $P B, C M B$ and $C B$ which will be determine purposively. The primary data was collected by interviewing the staffs and the officials of the relevant authorities regarding the implementation of $P B, C M B$ and $C B$. The primary data was collected from the prisoners and their family, whether they apply for the $P B, C M B$ or $C B$ or not. The data analysis was carried out continuously from the beginning to the end of the research by doing data triangulation, through assessment, categorization, evaluation, comparison and synthesis. The result of the research: First, the implementation process of $P B, C M B$ and $C B$ to the prisoners is already carried out Tim Pengamat Pemasyarakatan (TPP) Correctional Institution in Bengkulu, Pembimbing Kemasyarakatan (PK) Balai Pemasyarakatan (Bapas) Bengkulu and TPP Regional Office of Ministry of Law and Human Rights in Bengkulu. However, the implementation process is not quite fair and equitable since not all of the prisoners can apply for $P B, C M B$ or $C B$ because they do not have enough money and guarantor.There is a certain amount of money that needs to be paid by the prisoners as the documentation fee, although there is
\end{abstract}

1 Penulis adalah Staf Pengajar Fakultas Hukum dan FISIP Universitas Bengkulu. Alamat kontak: nswrahardjo@yahoo.co.id. 
an anti-halinar program which prohibits fee collection. In June 2013, there was a program, called crash program, which helped the prisoners who do not have money and guarantor to apply for $P B, C M B$ or $C B$, but only a few of them got the benefit of this program. Second, the are obstacles in the implementation of $P B, C M B$ and $C B$. In their implementation from 2012 to 2013, some of the obstacles are regarding administrative issues. The research team proposes for the distinction between the model concept of $P B, C M B$ and $C B$ for the special crime prisoners and general crime prisoners. The research team proposes that the fair and equitable $P B, C M B$ and $C B$, in the form of crash program, should be given free of charge to the general crime prisoners, and for the special crime prisoners should pay certain amount of fee as determined by the authority.

Keywords: prisoners, $P B, C M B, C B$, fair and equitable outside institution development, the purpose of correctional system

\begin{abstract}
Abstrak
Tujuan yang hendak dicapai pada penelitian tahun pertama: penjelasan proses pelaksanaanPembebasan Bersyarat (PB), Cuti Menjelang Bebas (CMB) dan Cuti Bersyarat (CB) pada narapidana (napi), kendala-kendala dalam pelaksanaannyadan tersusunnya konsep model sistempembinaan luar lembaga bagi napi yang merata dan berkeadilan berperspektif pada tujuan Pemasyarakatan.Tahun kedua: melakukan lokakaryahasil penelitian tahun pertama melalui uji silang dengan makalah pembanding dari Kanwil kementerian hukum dan Ham Provinsi Bengkulu, Lembaga Pemasyarakatan (Lapas) Bengkulu dan Balai Pemasyarakatan (Bapas) Bengkulu,sehingga tersusun konsep model sistempembinaan luar lembaga bagi napi yang merata dan berkeadilan berperspektif pada tujuan Pemasyarakatan secara komprehensif. Hasil lokakarya ini akan menjadi masukan bagi Dirjen Pemasyarakatan Kementerian Hukum dan Ham dalam membuat kebijakan pembinaan luar lembaga bagi napi. Penelitian ini bersifat deskriptifeksplanatif dengan pendekatan Sosiologi Hukum. Teknik pengambilan data dengan kuisioner, wawancara mendalam, pengamatan dan studi dokumentasi berupa mempelajari Penelitian Kemasyarakatan (Litmas) dan berkas PB, $C M B$ dan $C B$ yang ditentukan secara purposive. Aspek yang digali dari informan, berupa data primer tentang proses pelaksanaan $P B, C M B$ dan $C B$ dan kendala yang dihadapi. Data primer digali dari informan petugas dan informan napi baik yang mengajukan $P B, C M B$ atau $C B$ maupun yang tidak mengajukan, serta keluarga napi yang mengajukan. Analisis data dilakukan secara terus menerus sejakawal hingga akhir penelitian dengan melakukan triangulasi data, melalui pengujian, pemilahan, kategorisasi, evaluasi, mengkomparasikan dan melakukan sintesa, hingga tersusun dalam sebuah laporan penelitian. Hasil penelitian: (1) Proses pelaksanaan PB, CMB dan CB pada napi yang dilaksanakan oleh Wali Pemasyarakatan, Tim Pengamat Pemasyarakatan (TPP) Lapas Bengkulu, Pembimbing Kemasyarakatan (PK)
\end{abstract}


Bapas Bengkuludan TPP Kanwil Kemkumham Bengkulu sudah berjalan, tetapi belum merata dan berkeadilan. Tidak semua napibisa, mengajukan, terutama pada napi yang tidak mempunyai penjamin dan tidak mempunyai sejumlah uang, karena dana pemberkasan dari DIPA tidak mencukupi. Ada dana dalam jumlah tertentu yang harus dikeluarkan napi untuk membantu biaya pemberkasan, meskipun ada program anti hp, pungli dan narkoba (antihalinar) yang melarang adanya pungutan. Tentang adanya uang yang harus dikeluarkan, napi menyatakan sebagai ucapan terima kasih karena petugas telah membantu pemberkasan PB, CMB atau CB. Di sisi lain Lapas dan Bapas membuka peluang petugasnya diberi uang oleh napi, batasannya petugas tidak boleh meminta, tetapi bila diberi diterima. Pada bulan Juni 2013 ada crash program yang cukup membantu napi yang tidak memiliki uang dan penjamin, hanya saja jumlah napi yang mendapat program ini jumlahnya sedikit. (2) Kendala: dalam pelaksanaannya pada tahun 2012 hingga 2013 sering ada perubahan aturan, penerbitan surat keterangan bahwa napi tidak sedang ada perkara lain oleh Kejaksaan sering terlambat, ada napi yang tidak mempunyai penjamin dan tidak memiliki uang untuk pengurusan PB, CMB atau CB. Sarana dan prasarana di Lapas dan Bapas terbatas,pembuatan litmas terlambat, penerbitan SK PB dan CB cukup lama. Program anti-halinar belum berjalan efektif karena masih banyak napi yang harus mengeluarkan sejumlah uang untuk pengurusan $P B, C M B$ atau CB. (3) Tim peneliti mengajukan pembedaan konsep model pelaksanaan $P B, C M B$ atau $C B$, bagi napi pidsus dan napi pidum,supaya $P B, C M B$ atau $C B$ merata dan berkeadilan dalam bentuk crash program yang harusdiberikan gratis pada napi pidum, sedangkan napi pidsus dibebani biaya yang ditetapkan oleh pejabat yang berwenang. Model ini akan mendukung tujuan Pemasyarakatan.Pembinaan luar lembaga bagi napi yang telah menjalani $P B, C M B$ atau $C B$ oleh Bapas harus makin ditingkatkan dan bertumpu pada pembinaan keterampilan bagi napi pidum sedangkan bagi napi pidsus lebih dititik beratkan pembinaan mental spiritual. Kesimpulan: pelaksanaan $P B, C M B$ dan $C B$ sudah berjalan tetapi belum efektif karena berbagai kendala. Tim peneliti menawarkan model pelaksanaan $P B, C M B, C B$ dan pembinaan luar lembaga yang merata dan berkeadilan, untuk mendukung pelaksanaan tujuan Pemasyarakatan Saran: peran Wali Pemasyarakatan harus ditingkatkan, agar program anti-halinar bisa berjalanperlu peningkatan dana pemberkasan dalam DIPA, atau melaksanakan modelyang diajukan tim peneliti. Peranan Bapas ditingkatkan guna pelaksanaan pembinaan luar lembaga danSistem Informasi Pemasyarakatan harus segera dilaksanakan.

Kata kunci: narapidana, Pembebasan Bersyarat (PB), Cuti Menjelang Bebas $(C M B)$, Cuti Bersyarat $(C B)$, model pembinaan luar lembaga yang merata dan berkeadilan, tujuan Pemasyarakatan. 


\section{Pendahuluan}

Konsideran UU No. 12 Tahun 1995 menyebutkan, penjatuhan sanksi penjara bagi narapidana (napi), tidak hanya bertujuan menghukum saja, tetapi merupakan rangkaian penegakan hukum supaya napi menyadari kesalahannya, memperbaiki diri, tidak mengulangi perbuatannya dan dapat diterima kembali oleh lingkungan masyarakatnya.Artinya Lembaga Pemasyarakatan (Lapas) adalah tempat untuk membina dan mendidik napi supaya dapat kembali menjadi manusia yang berguna dalam masyarakatnya.

Kenyataan menunjukkan sebaliknya, pada umumnya Lapas di Indonesia mengalami kelebihan penghuni. Pada tahun 2007, penghuni Lapas di 525 lokasi Lapas dan Rutan di seluruh Indonesia mencapai 118.453 orang padahal kapasitasnya hanya untuk 76.550 orang. Jadi ada kelebihansekitar 54,73\%. Disamping itu fasilitas kesehatan yang sangat minim, buruknya sanitasi dan rendahnya gizi makananan, mengakibatkan, 813 orang napi pada tahun 2006 meninggal dunia. Berbagai penyakit seperti penyakit saluran pernapasan, TBC, pencernaan dan HIV/AIDS, sangat mengancam jiwa napi. Pada tahun 2010 menurut Menteri Hukum dan Ham, Patrialis Akbar, kelebihan kapasitas Lapas mencapai 55.000 orang. Saat itu penghuni Lapas 135.000 orang sementara kapasitas normalnya hanya untuk 80.000 orang, sehingga ada kelebihan kapasitas sebesar7,26\%. ${ }^{2}$

Kondisi ini menimbulkan ketidak nyamanan dan mudah untuk menyulut konflik antar napi. Konflik benar-benar terjadi di Lapas Tanjung Gusta Medan Sumatera Utara pada tanggal 11 Juli 2013 menjelang orang berbuka puasa, faktor pemicunya:

1. Listrik mati dan air tidak mengalir, akibatnya napi berontak dan menjebol pintu utama serta membakar ruangan kantor.

2. Penghuni Lapas Tanjung Gusta melebihi kapasitas. Jumlah hunianper 11 Juli 2013 adalah 2.600 orang, terdiri dari 2.594 napi dan 6 orang tahanan, padahal kapasitas Lapas hanya untuk 1.054 orang.

3. Napi memprotes PP No. 99 Tahun 2012 yang menyebutkan napi khusus korupsi, narkoba dan terorisme tidak mendapat remisi, termasuk remisi yang biasa diberikan pada setiap ulang tahun hari kemerdekaan Indonesia 17 Agustus.

Potensi konflik akibatkelebihan kapasitas hampir merata di semua Lapas atau Rutan di seluruh Indonesia. Dari total 457 Lapas atau Rutan hanya 59 $(12,9 \%)$ yang penghuninya dibawah kapasitas. Sementara $398(87,1 \%)$ Lapas atau Rutan mengalami kelebihan kapasitas, sehingga napi harus hidup berdesak-desakan dengan napi lainnya. Jumlah napi dan di dalam penjara pada tahun 2013 sebanyak 162.025 orang, padahal kapasitasnya hanya 108.160

\footnotetext{
${ }^{2}$ Harian Kompas, 21 April 2007, Mengantar Maut di Lembaga Pemasyarakatan, dalam rublik Fokus, hal. 33,39 dan Harian Kompas 18 Juli 2010, LP Kelebihan Penghuni 55.000 Orang, hal. 2.
} 
orang. Artinya terdapat kelebihan penghuni 53.865 (50\%) orang. Jumlah pegawai Ditjen Pemasyarakatan sekitar 29.000 orang, jumlah tersebut termasuk dirjen, pejabat eselon II, III, IV di Ditjen Pemasyarakatan, Kanwil Kemkumham, serta petugas di Lapas dan Rutan bagian administrasi, kesehatan dan sektor-sektor pendukung lainnya. Ditjen Pemasyarakatan tidak berwenang merekrut pegawai, bahkan menentukan anggaran, semua di bawah Setjen Kemkumham. Menghadapi situasi yang seperti ini menurut Akbar Hadi Prabowo, Humas Ditjen Pemasyarakatan Kemkumham, petugas Lapas hanya bisa berdoa, berharap tidak terjadi apa-apa. Manajemen "doa", itulah ungkapan Akbar untuk menggambarkan bagaimana pengamanan dilakukan, khususnya untuk petugas-petugas di Lapas yang kelebihan penghuni. Berbagai upaya dilakukan untuk menjaga kondisi Lapas dan Rutan supaya tetap aman, menurut Bambang Sumardiono Kepala Lapas Klas IA Porong, Surabaya Jawa Timur, trik yang digunakan adalah mengedepankan pendekatan personal, memperluas jaringan ke napi, petugas sering turun ke blok-blok tahanan untuk menyapa napi, supaya terjalin hubungan emosi yang baik dengan para napi. ${ }^{3}$

Undang-undang telah menyediakan cara mengurangi kelebihan kapasitas Lapas, dalam bentuk remisi, asimilasi, PB, CMB dan CB berdasarkan Peraturan Menteri Hukum dan HAM (Permenkumham) yang terus mengalami perubahan, yaitu Permenkumham No. M01.PK.04-10 tahun 2007, yang diubah Permenkumham No. 21 tahun 2013. Para napi yang memenuhi persyaratan tertentu berhak mengajukan salah satu hak tersebut sesuai dengan kebutuhan napi.

Selama napi berada di dalam Lapas, ada beberapa tahap pembinaan yaitu:

1. Tahap pertama: Tahap maximum security, hingga1/3 dari masa pidana yang harus dijalani para napi;

2. Tahap kedua: Tahap medium security, sampai batas $1 / 2$ dari masa pidana yang harus dijalani para napi;

3. Tahap ketiga: Tahap minimum security sampai batas $2 / 3$ dari masa pidana yang harus dijalani para napi;

4. Tahap keempat: Tahap integrasi dari $2 / 3$ hingga masa pidananya berakhir. $^{4}$

Pada tahap minimum security dan integrasi napi dapat keluar dari Lapas dengan tujuan beradaptasi dengan masyarakatnya dan menjadi bagian masyarakatnya kembali, dengan cara mengajukan Pembebasan Bersyarat (PB), Cuti Menjelang Bebas (CMB) atau Cuti Bersyarat (CB), sehingga napi berada di luar Lapas dan mengurangi kelebihan kapasitas Lapas.

\footnotetext{
${ }^{3}$ Harian Kompas, 13 Juli, 2013, Ada “Bom Waktu” di Penjara, halaman 1 \& 15 dan Harian Kompas, 16 Juli 2013, Lembaga Pemasyarakatan, Manajemen "Doa: di Penjara, halaman 5.

${ }^{4}$ HR. Soegondo 1994, Prinsip-prinsip Konsepsi Pemasyarakatan Hasil Konferensi Lembang 1964 Serta Pengebangannya Dewasa Ini, makalah, disampaikan dalam ceramah pada SARPENAS II IKA-AKIP, Departemen Kehakiman RI, 27 April 1994, hal. 11-14
} 
Rahadi Ramelan, mantan Menteri Negara Riset dan Teknologi di era tahun 1998 yang pernah menjadi penghuni Lapas, berpendapat:

Selain merupakan hak napi, program $P B, C M B$ dan $C B$, juga bertujuan untuk mengatasi masalah jumlah napi yang melebihi kapasitas (over capacity) dan mengurangi anggaran Pemerintah dalam pembinaan dan perawatan napi di sejumlah Lapas, karena dengan diberikan hak $P B, C M B$ atau $C B$ kepada napi yang telah memenuhi syarat, maka napi itu tidak dibina lagi di dalam Lapas, tetapi dibina di tengah-tengah masyarakat. ${ }^{5}$

Meskipun PB, CMB dan $\mathrm{CB}$, merupakan hak napi, tetapi tidak dengan serta merta napi bisa memperolehnya. Hasil penelitian Poppy Hartati di Lapas Curup Kabupaten Rejang Lebong provinsi Bengkulu menunjukkan, bahwa jumlah napi yang memperoleh $\mathrm{PB}, \mathrm{CMB}$ atau $\mathrm{CB}$ relatif kecil.

Untuk PB, pada tahun 2007 napi yang berhak sebanyak 68 orang, tetapi yang memperoleh $P B$ hanya 41 orang, tahun 2008, napi yang berhak72 orang tetapi yang memperoleh hanya 45 orang,pada tahun 2009 napi yang berhak sebanyak 62 orang yang menerima 47 orang. Untuk CMB, pada tahun 2007, napi yang berhak sebanyak 16 orang, tetapi yang memperolehnya hanya 4 orang. Pada tahun 2008, yang berhak12 orang dan yang memperoleh hanya 1 orang. Pada tahun 2009 yang berhak memperoleh CMB10 orang, tetapi yang memperolehnya 3 orang. CB baru dilaksanakan pada tahun 2008, napi yang berhak sebanyak 57 orang, yang memperolehnya hanya 32 orang. Pada tahun 2009, napi yang berhak48 orang, yang memperolehnyal5 orang. Kecilnya jumlah napi yang memperoleh $P B, C M B P B$ ini, karena Dirjen Pemasyarakatan tidak menganggarkan biaya untuk pengurusan administrasi dan pemberkasan $P B, C M B$ atau $C B$, dan para napi yang berkepentingan harus menanggung biaya tersebut. ${ }^{6}$

Penyebab lainnya, terungkap dari hasil tugas mahasiswa pada mata kuliah Bantuan Hukum dan Penyantunan Narapidana (BHPT) : pengajuan PB, CMB dan $\mathrm{CB}$ biayanya cukup tinggi, untuk $\mathrm{PB}$, setiap napi mengeluarkan uang Rp. 1.300.000,- sampai Rp. 1.500.000,- dan SK-nya akan turundalamwaktu 2 bulan,bila mau lebih cepat biayanya Rp.2.500.000,-. Untuk CB, sebesar Rp.600.000,- ini lebih murah, karena cukup dibuat di Kanwil

${ }^{5}$ Harian Kompas, 19 Mei 2007, hal. 15.

${ }^{6}$ Poppy Hartati, 2009, Pelaksanaan Pembebasan Bersyarat, Cuti Menjelang Bebas dan Cuti Bersyarat Pada Narapidana Di Lembaga Pemasyarakatan Kelas IIA, Curup, Skripsi, Fakultas Hukum UNIB, hal. 55-61. 
Kemkumhamsedangkan untuk PB yang membuat SK adalah Dirjen Pemasyarakatan Kemkumham. ${ }^{7}$

Adanya biayabesar menunjukkan sistem yang ada tidak berjalan dengan baik. Bila kondisi seperti ini terus berlangsung, persoalan kelebihan kapasitas di Lapas tidak akan pernah terselesaikan dengan tuntas. Dampaknya kejadian seperti di Lapas Tanjung Gusta Medan akan berulang dantujuan Pemasyarakatan yang diamanatkan oleh UU No. 12 Tahun 1995 terancam gagal, oleh karena itu diperlukan model sistempelaksanaan PB, CMB dan CB, yang bisa menjangkau sebanyak mungkin napisupaya semua napimemperoleh dan menikmati haknya secara merata dan berkeadilan.Berdasar latar belakang di atas, penelitian ini dilakukan.Masalah yangdikaji dalam penelitian tahun I adalah bagaimana proses pelaksanaanPB, CMB atau CB pada napi yang telah memenuhi syarat,apa kendala dalam pelaksanaannya dan bagaimana menyusun konsep model sistem pembinaan luar lembaga bagi napi yang merata dan berkeadilan berperspektif pada tujuan Pemasyarakatan. Pada tahun II, dilakukan lokakaryahasil penelitian tahun pertama melalui uji silang dengan makalah pembanding dari Kanwil Kemkumham Provinsi Bengkulu, Lembaga Pemasyarakatan (Lapas) Bengkulu dan Balai Pemasyarakatan (Bapas) Bengkulu, sehingga tersusun konsep model sistem pembinaan luar lembaga bagi napi yang merata dan berkeadilan berperspektif pada tujuan Pemasyarakatan. Hasil lokakarya akan menjadi masukan bagi Dirjen Pemasyarakatan Kemkumham dalam membuat kebijakan pembinaan luar lembaga bagi napi.

\section{Metode Penelitian}

Penelitian ini menggunakan metode kualitatif, yang menghasilkan data deskriptif-eksplanatif dengan pendekatan yuridis-empiris berdasarkan Sosiologi Hukum. ${ }^{8}$ Lokasi penelitian ini di Lapas Bengkulu,Bapas Bengkulu dan Kanwil Kemkumham Propinsi Bengkulu. Sumber data primer diperoleh dari kelompok informan yang dikategorikan Tim Pengamat Pemasyarakatan (TPP) Lapas Bengkulu, Pembimbing Pemasyarakatan (PK) Balai Pemasyarakatan (Bapas) Propinsi Bengkulu serta TPP Kanwil Kemkumham Propinsi Bengkulu. Berikutnya kelompok informan yang dikategorikan sebagai napi yang mengajukan atau tidak mengajukanPB, CMB, $\mathrm{CB}$ dan keluarga pemohon. ${ }^{9}$ Data sekunder diambil dari undang-undang, literatur, litmas dan berkas $\mathrm{PB}, \mathrm{CMB}$ dan $\mathrm{CB}$. Pengumpulan data primer menggunakan kuisioner, wawancara mendalam, pengamatan dan mempelajari data sekunder. Analisis data meliputi pengujian, pemilahan, kategorisasi, evaluasi, mengkomparasikan,

\footnotetext{
${ }^{7}$ Rizky, Febrianti, dkk, 2011, Tugas Mata Kuliah BHPT tentang Pelaksanaan PB, CMB dan CB di Lapas Bengkulu, Fak Hukum UNIB, hal.14,15.

8 Soerjono Soekanto, 1990, Ringkasan Penelitian Hukum Empiris, Rajawali Pers, Jakarta, hal 23.

${ }^{9}$ LexyMoleong 2006, Metodologi Penelitian Kualitatif, Bandung, Rosdakarya, hal. 157.
} 
melakukan sintesa dan mencari keterikatan berbagai konsep berdasar analisis Sosiologi Hukum. ${ }^{10}$ Dengan cara ini proses pembinaan luar lembaga yang adil dan merata dapat dideskripsikan dan dieksplanasikan dalam kualitas yang lebih mendekati kenyataan serta terungkap hal-hal yang melatar belakanginya.

\section{Hasil dan Pembahasan}

\section{Proses Pelaksanaan PB, CMB dan CB Pada Narapidana yang telah Memenuhi Persyaratan}

Pada saat penelitian dilakukan ada perubahan peraturan untuk pengajuan PB, CMB dan CB. Peraturan lama tertuang dalam Peraturan Menteri Hukum dan Ham (Permenkumham) RI No. M 01. PK.04. 10 tahun 2007 tentang Syarat dan Tata Cara Pelaksanaan Asimilasi, PB, CMB dan CB Jo.Permenkumham RI No. M.HH.01.PK.05.06 tahun 2008 tentang Perubahan Atas Permenkumham No. M 01. PK.04. 10 tahun 2007 Jo. Pemenkumham RI No. M.HH-02.PK.05.06 tahun 2010 tentang Perubahan Kedua Atas Permenkumham No. M 01. PK.04. 10 tahun 2007 digantikan atau diubah oleh Permenkumham No 21 tahun 2013 tentang Syarat Dan Tata Pemberian Remisi, Asimilasi, Cuti Mengunjungi Keluarga, PB, CMB dan CB.

Adanya dua peraturan yang berlaku ini dalam pelaksanaannya, untuk napi yang eksekusi putusan hakim atas perkaranya dilakukan sebelum 12 November 2012 menggunakan aturanlama (Permenkumham RI No. M 01. PK.04. 10 Tahun 2007 tentang Syarat dan Tata Cara Pelaksanaan Asimilasi, PB, CMB dan CB Jo.Permenkumham RI No. M.HH.01.PK.05.06 Tahun 2008 tentang Perubahan Atas Permenkumham No. M 01. PK.04. 10 Tahun 2007 Jo. Pemenkumham RI No. M.HH02.PK.05.06 Tahun 2010 tentang Perubahan Kedua Atas Permenkumham No. M 01. PK.04. 10 Tahun 2007)sedangkan yang dieksekusi setelah 12 November 2012 menggunakan Permenkumham No. 21 Tahun 2013. Perubahan mendasar dalamPermenkumham No 21 tahun 2013 ditujukan pada napi pelaku tindak pidana terorisme, narkotika dan prekusor narkotika, korupsi, kejahatan hak asasi manusia yang berat serta kejahatan transnasional (napi pidsus), untuk memperoleh hak-haknya ada persyaratan khusus yang harus dipenuhi, seperti harus membayar uang denda, mengikuti asimilasi dan menjadi justice collaborator.

Dari penelitian ini, didapatkan data mengenai kenyataan di lapangan yang berbeda dengan peraturan yang ada.Menurut Kepala Seksi Bimbingan Narapidana dan Anak Didik (Kasi Binadik) dan Kepala Sub Seksi Bimbingan Kemasyarakatan dan Perawatan (Kasubsi Bimkemaswat) Lapas Bengkulu, proses pengajuan PB, CMB atau CB, diawali dengan terpenuhinya persyaratan substantif dan administratif

${ }^{10}$ Lexy Moleong, Op. Cit., hal. 287-292. 
oleh napi.Apabila syarat-syarat telah terpenuhi, para napiakan mendapat arahan, bantuan dan pendampingan dari Wali Pemasyarakatan. Idealnya Wali Pemasyarakatan mendampingi sejak napi berada di Lapas, tetapi kenyataannya hanya padasaat napi mengajukan $\mathrm{PB}, \mathrm{CMB}$ atau $\mathrm{CB}$ saja. Untuk kelengkapan persyaratan administratif seperti surat keterangan dari Lurah atau Kepala Desa dan surat jaminan diurus oleh keluarga, sedangkan surat keterangan dari Kejaksaan akan diurus oleh Lapas. Pihak Kejaksaan mengeluarkan surat keterangan yang menyatakan bahwa napi yang bersangkutan tidak mempunyai perkara lain yang belum diputus.

Bersamaan dengan proses pemberkasan, pihak Lapas mengirim surat kepada Bapas, supaya napi yang mengajukan $\mathrm{PB}$ dan $\mathrm{CMB}$ dibuatkan penelitian kemasyarakatan (litmas) oleh Pembimbing Kemasyarakatan (PK) Bapas. Untuk CB tidak memerlukan litmas dari Bapas, tetapi Wali Pemasyarakatan akan membuat Laporan Pembinaan Warga Binaan Pemasyarakatan sebagai pengganti litmas. Setelah semua persyaratan lengkap maka akan dibahas dalam sidang Tim Pengamat Pemasyarakatan (TPP) Lapas. Untuk pemberkasan PB, CMB atau CB, sebelum tahun 2010 tidakada anggarannya, tetapi hanya disebutkan sebagai anggaran untuk persidangan TPP saja. Sejak tahun 2010 anggaran pemberkasan PB, CMB dan CB bersumber dari DIPA. Anggara tahun 2012 sebesar Rp.12.000.000 setahun dan pada tahun 2013 diusulkan menjadi Rp.18.000.000,-, tetapi realisasinya tetap Rp.12.000.000,-. Atas kebijakan Kepala Lapas, dana tersebut dibagi untuk 12 bulan. Jika dengan perkiraan perbulan ada 30 orang napi yang mengajukan PB, CMB atau CB, maka dana pemberkasan sekitar Rp.35.000,- per napi. Pengalokasiannya Rp. 30.000,- untuk proses pemberkasan, berupa foto kopi berkas, sedangkan Rp. 5000,- untuk konsumsi pelaksanaan sidang TPP Lapas. Biaya cuci cetak foto napidan pembelian meterai, ditanggung oleh napi itu sendiri. Khusus untuk pemohon PB, CMB atau CB karena kasus narkoba, dikenai tambahan biaya Rp.100.000,- untuk tes urine, bila napi yang bersangkutan melakukan tes urine di Lapas, tetapi napi bebas memilih mau tes urine di Lapas atau di luar. Semua kelompok informan dari petugas Lapas, Bapas dan Kanwil Kemkumham Provinsi Bengkulu menyatakan bahwa pada prinsipnya tidak ada sama sekali pungutan biaya untuk pengurusan $\mathrm{PB}, \mathrm{CMB}$ atau $\mathrm{CB}$.

Realitasnya, dana pemberkasan yang dialokasikan sebesar Rp.30.000,-tidak mencukupi. Oleh karena itu Kasubsi Bimkemaswat mentolerir adanya pemberian suka rela biaya pemberkasan dari napikepada Wali Pemasyarakatan maksimal Rp. 100.000,-,. Batasannya adalah Wali Pemasyarakatan dilarang keras meminta, tetapi pemberianatas dasar kesukarelaan dari napi diperbolehkan. Ketika tim peneliti menanyakan bila benar-benar biaya pemberkasan kurang, sementara napi tidak memberi tambahan biaya, Kasubsi Bimkemaswat menjawab akan dilakukan subsidi silang. Teknis pelaksanaannya, untuk pemberkasan yang tidak memerlukan banyak foto kopi, yaitu 
pemberkasan $\mathrm{CB}$ danPB tindak pidana umum, akan mensubsidi pemberkasan yang banyak dan tebal seperti tindak pidana korupsi sehingga mengurangi kendala pembiayaan.

Untuk pemberkasan sebagian besar napi yang menjadi informan menyatakan memberikan uangantara Rp.100.000,- sampai Rp.300.000,-. Menurut napi pemberianini sebagai ucapan terima kasih pada Wali Pemasyarakatan, karena telah membantu pengurusan $\mathrm{PB}$ atau $\mathrm{CB}$ napi. Jumlahnya memang tidak sebesar data dari hasil tugas mahasiswa yang dikemukakan dalam bagian pendahuluan artikel ini, tetapi realitasnya tetap ada biaya yang dikeluarkan oleh napi diluar pas photo dan meterai.

Pada tahun 2013 berdasar Surat Dirjen Pemasyarakatan No. PAS.PK.01.05.06-124 tanggal 24 Mei 2013 ada crash program untuk pengusulan $\mathrm{PB}, \mathrm{CMB}$ dan $\mathrm{CB}$ secara gratis bagi napi yang 2/3 masa pidananya jatuh sebelum tanggal 17 Agustus 2013. Jumlahnya sebanyak 20.000 orang di seluruh Indonesia. Namun program ini dikecualikanbagi napi yang masuk dalam kategori Pasal 34A ayat (1) PP No. 99 Tahun 2012. Artinya crash program tidak diberikan kepada napi pidsus. Persyaratannya lebih sederhana, yaitu tidak diperlukan persyaratan pembuatan litmas, tetapi diganti laporan perkembangan perilaku napi selama di Lapas yang dibuat oleh Wali Pemasyrakatan (dibuat litmas dalam), ditandatangani oleh Kepala Bapas. Di Lapas Bengkulu napi yang diusulkan sebanyak 29 orang tetapi yang mendapatkan crash program sebanyak 24 orang, 5 orang napi lainnya ditolak karena 2/3 masa pidana yang harus dijalani jatuh sesudah 17 Agustus 2013.

Menurut penjelasan seorang informan yang berstatus sebagai pejabat di jajaran Kemkumham Provinsi Bengkulu, bahwa crash program, merupakan program yang dibuat karena kondisi panik, dampak adanya isu pada tanggal 16 Agustus 2013 akan terjadi kerusuhan di seluruh Lapas dan Rutandi Indonesia, karena penerapan PP No. 99 tahun 2012 Jo. Permenkemkumham No. 21 tahun 2013. Berangkat dari isu tersebut maka Wakil Menteri Hukum dan Ham menggulirkan crash program, untuk meredam dan mengantisipasi isu kerusuhan, khusus bagi napi yang tidak masuk kategori Pasal 34 A ayat (1) PP No. 99 tahun 2012 (bukan napi napi tindak pidana terorisme, narkotika dan prekusor narkotika \& psikotropika, napi korupsi, kejahatan terhadap kamanan negara, kejahatan HAM berat, serta kejahatan transnasional terorganisasi). Peneliti mempertanyakan, kenapa kerusuhan akan dilakukan oleh seluruh napi padahal yang terdampak oleh PP No. 99 Tahun 2012 Jo. Permenkemkumham No. 21 Tahun 2013ini napi pidsus. Informan menyatakan, kondisi ini diciptakan oleh para napi pidsus dengan cara mempengaruhi seluruh napi untuk melakukan pemberontakan, karena mereka mempunyai kekuasaan dan uang untuk mempengaruhi napi yang tidak punya kepentingan apapun dengan peraturan tersebut. Kepala Devisi (Kadiv) Pemasyarakatan Kanwil Kemkuham Provinsi Bengkulu tidak sependapat bahkan membantahpernyataan di atas. Menurut Kadiv Pemasyarakatan crash program adalah salah satu upaya untuk 
mengurangi kelebihan kapasitas Lapas, hanya saja PP No.99 tahun 2013 dan Permenkemkumham No. 21 tahun 2013 ini dibuat tergesa-gesa, akibatnya menimbulkan kebingungan petugas dan napi dalam penerapannnya.

Dalam pembuatan litmas untuk PB dan CMB di Bapas, Kepala Bapas dan dua orangPK Bapas menyatakan tidak ada pungutan, semua dibebankan pada DIPA Bapas. Pada tahun 2012 anggarannya sebesar Rp. 160.000.000,-, untuk400 berkas litmasmeliputi pembuatan litmas PB dan CMB bagi napi dewasa, napi anak dan litmas persidangan anak. PK Bapas menjelaskan pada tahun 2012 ada 693 orang yang perlu dibuatkan litmas untuk PB,CMB dan litmas untuk persidangan anak, sementara Bapas hanya memperoleh dana DIPAuntuk 400 orang, jadi ada 293 orang $(73,25 \%)$ yang harus dibuatkan litmasnya tanpa anggaran dari negara. Disamping itu wilayah kerja Bapas Provinsi Bengkulu yang meliputi sembilan kabupaten dan satu kota, juga menjadi kendala dalam pembuatan litmas. Jarak tempuh terjauh adalah kabupaten Muko-muko 490 km, kabupaten Kaur 320 km dan kabupaten Lebong 200 km. Bapas menetapkan biaya untuk PK Bapas dalam mencari data litmas sebagai berikut: untuk Kota Bengkulu Rp.40.000,-per litmas, Kabupaten Kepahiang Rp.100.000,-, kabupaten Rejang Lebong Rp.180.000,-, kabupaten Lebong Rp.200.000,-, kabupaten Seluma Rp.150.000,kabupaten Bengkulu Selatan Rp.150.000,-, kabupaten Kaur Rp.240.000,, kabupaten Bengkulu Tengah Rp. 150.000,- kabupaten Bengkulu Utara Rp.180.000,-, kabupaten Muko-muko Rp. 300.000,-- per litmas. Alokasi dana ini,tidak seimbang atau kurang, terutama untuk biaya transportasi dan akomodasi bila tempat tinggal penjamin dari napi yang akan dibuatkan litmasnya jauh dari kota dan harus masuk kepedesaan. Kendala dana ini berdampak dalam pembuatan litmas.Data yang seharusnya diambil dalam kunjungan ke tempat tinggal penjamin, hanya diambil dari hasil wawancara PK Bapas dengan napi atau keluarga napi pada saat keluarga menyerahkan berkas surat ke Bapas.

Pada saat di cross check data dengan informan kelompok napi dan keluarga napi, terungkap bahwa ada permintaan sejumlah uang kepada napi dan keluarganya untuk pembuatan litmas oleh petugas PK Bapas. Kepala Bapas dan PK menanggapi, bahwa adanya oknum PK yang meminta itu mungkin terjadi, tetapi secara institusional tidak pernah ada kebijakan untuk menarik uang dari klien, karena ini bisa dikategorikan sebagai gratifikasi. Kepala Bapas tidak memungkiri, bila ada keluarga napi yang memberi uang untuk pembuatan litmas pada PK. Menurut Kepala Bapas boleh diterima, tetapi PK Bapas dilarang meminta uang dari pemohon litmas.

Proses pengajuan PB, CMB,CB di Lapas, setelah pemberkasan selesai dan syarat substantif serta syarat administratif telah terpenuhi dan lengkap, maka TPP Lapas Bengkulu akan melakukan sidang. Sidang di tingkat TPP Lapas ini satu bulan dua kali dan berkas yang disidangkan rata-rata 30 buah, tetapi untuk $\mathrm{CB}$ tidak tertutup kemungkinan ada berkas 
susulan sebanyak dua atau tiga berkas tetap disidangkan. Ini disebut sidang TPP berjalan, dengan tujuan supaya pengajuan CB ini bisa diikut sertakan pada periode tersebut sehingga pelaksanaan $C B$ napi tidak terlambat.

Untuk pembinaan napi yang tertib, Kemkumham memiliki program getting to zero halinar, dengan sasaran penghuni Lapas bebas penggunaan handphone, bebas pungli dan bebas narkoba. Hal ini didasarkan pada Permenkumham No.6 tahun 2013. Disamping itu, ada aturan untuk mengatur perilaku petugas di jajaran Kemkumham yaitu Permenkumham No. M.MH-07.KP.05.02 tahun 2012 tentang Kode Etik Pegawai Negeri Sipil di Lingkungan Kemkumham, berlaku tanggal 12 Februari 2012. Realisasi dari kedua aturan tersebut adalah di setiap Lapas atau Rutanada binner yang menggambarkan tata tertib yang berlaku bagi pengunjung di Lapas, hak dan kewajiban napi, serta larangan-larangan bagi petugas, napi dan tahanan, serta pengunjung. Untuk mengefektifkan peraturan ini, dicantumkan nomor telpon pengaduan, nomor tersebut adalah 081919400090 atau facebook Kanwil Kemenkumham Bengkulu dan email: kanwil.bengkulu@kemenkumham.go.id.

Proses pengusulan $\mathrm{PB}, \mathrm{CMB}$ atau $\mathrm{CB}$ di tingkat TPP Kanwil Kemkumham Provinsi Bengkulu adalah sebagai berikut: usulan PB, CMB atau CB dari Lapas Bengkulu diterima oleh Kepala Sub Bidang Bimbingan Kemasyarakatan Latihan Kerja dan Produksi (Kasubbid Bimkemaslatkepro), selaku kesektretariatan TPP Kanwil Kemkumham Provinsi Bengkulu. Usulan kemudian diperiksa dan diteliti, berkas PB, CMB atau $\mathrm{CB}$ yang sudah lolos pemeriksaan dibuatkan ringkasan pada lembar korektor, sedangkan yang belum memenuhi persyaratan dikembalikan ke Lapas supaya dilengkapi lagi. Selanjutnya kesekretariatan TPP membuat lembar korektor untuk bahan sidang TPP, kesekretariatan TPP membuat jadwal sidang dan undangan pada semua anggota TPP. Pada waktu sidang semua usulan dari seluruh Lapas atau Rutan disidangkan dan diteliti kembali. Usulan yang memenuhi persyaratan dibuatkan SK.,Untuk CMB dan CB yang menanda tangani SK adalah Kepala Kanwil Kumkemham Provinsi Bengkulu atas nama Menteri sedangkan untuk PB, diteruskan dan dikirim ke Dirjen Pemasyarakatan, karena yang berhak menerbitkan SK PB adalah Dirjen Pemasyarakatan atas nama Menteri.

Dalam hal pelaksanaannya bila napi sudah mendapat SK PB,CMB, atau $\mathrm{CB}$, pembinaan dan pengawasannya dilakukan oleh Bapas. Sebutannapi dan anak didik pemasyarakatan (napi anak) berubah menjadi klien pemasyarakatan. Pembinaan luar lembaga bagi napi yang sedang menjalani $\mathrm{PB}, \mathrm{CMB}$ ataupun $\mathrm{CB}$ yang dilakukan oleh Bapas, realisasinya masih sebatas wajib lapor sebulan sekalibagipara klien pemasyarakatan. Bila ada klien pemasyarakatan yang selama 2 - 3 bulan tidak lapor baru pihak PK Bapas akan melakukan kunjungan lapangan (home visi)t ke tempat tinggal klien pemasyarakatan. 
Idealnya pembinaan luar lembaga yang dilaksanakan oleh Bapas disesuaikan dengan kebutuhan klien pemasyarakatan, sebagai contoh bila klien pemasyarakatan bermata pencaharian sebagai tukang bangunan, maka pembinaan Bapas berupa pelatihan keterampilan pertukangan. Pada saat ini pembinaan yang dilakukan oleh Bapas baru sebatas pertukangan, dan kursus menyetir. Pelatihan dilakukan setahun sekali bekerja sama dengan Dinas sosial atau dari pihak Kemkumham memang memprogramkan pelatihan tertentu. Peserta dalam setiap pelatihan adalah antara 20-30 orang. Bentuk pelatihannya terbatas (hanya pertukangan dan kursus menyetir), sehingga tidak menjangkau semua klien pemasyarakatan dengan bermacam jenis tindak pidana.

Dari data yangdikumpulkan dari kelompok informan yang dikategorikan sebagai napi dan keluarga napi, hasil pengumpulan data primer tahap pertama yang dijaring melalui kusioner, jawaban napi yang mengajukan PB dan CB,h ampir seragam. Mereka menyatakan tidak ada pungutan dari pihak Lapas, tetapi mereka mengakui bahwa mereka memberikan sejumlah uang atas kerelaansendiri,untuk kepentingan napi itu sendiri yaitu untuk tambahan biaya foto kopi danhanya sebagai ungkapan atau tanda ucapan terima kasih kepada Wali Pemasyarakatan. Pemberian itu menurut napinilainya tidak seberapa bila dibandingkan jerih lelah Wali Pemasyarakatan yang telah menolong mereka. Biaya yang harus dikeluarkan menurut napi relatif kecil, bila dibandingkan dengan kebebasan yang akan diperoleh.Di tingkat Lapas sekitar Rp.100.000,- hingga Rp. 300.000,- sedangkan di tingkat Bapas sekitar Rp.300.000,- hingga Rp.600.000,-

Di sisi lain napi yang tidak mengajukan $\mathrm{PB}$ atau $\mathrm{CMB}$ atau $\mathrm{CB}$ mengaku bahwa mereka tidak mengajukan karena tidak ada penjamin dan tidak memiliki sejumlah uang untuk pengurusannya tanpa ada penjelasan lebih lanjut. Hasil jawaban kusioner yang hampir seragam, itumembawa tim peneliti pada kesimpulan sementara (hipotesis), ada semacam pengarahan secara diam-diam dalam pengisian kusioner. Seorang napi yang cukup cerdas menanggapi, bahwa pengarahan untuk menjawab supaya seragam itu tidak ada. Menurutnya bagi orang yang institusinya diserang dan dicari kelemahan, kekurangan ataupun keburukannya maka ada beban psikologis tertentu. Lebih-lebih bagi napi yang masih berada di Lapas yang nasibnya masih ditentukandan berada dalam wilayah kekuasaan institusi tersebut, maka dalam mengungkapkan sesuatu yang dia ketahui harus sangat hati-hati dan ada unsur pembelaan pada institusinya. Bahwa pungli dalam pengurusan $\mathrm{PB}, \mathrm{CMB}$ atau $\mathrm{CB}$ pasti ada, hanya saja untuk mencari bukti yang sangat transparan tentang pungli itu tidak mudah, hanya ada fenomena saja.

Penelitian ini lebih lanjut mendapatkan data sebagai berikut:

1) Para napi yang mengambil $P B$,menyatakan pada saat masuk ke dalam Lapas, diberikan penjelasan tentang hak-hak dan kewajiban selama menghuni Lapas, yaitu mentaatitata tertib di Lapas, tidak membawa barang terlarang, alat komunikasi, narkoba, dan lain-lain. Mereka juga 
diberikan penjelasan bahwa mereka memiliki hak untuk mendapatkan makanan dan minuman yang layak, memperoleh remisi, asimilasi, PB, $\mathrm{CB}$ atau $\mathrm{CMB}$, dan cuti mengunjungi keluarga. Alasan napi mengajukan PB adalah: karena ia ingin segera berkumpul bersama keluarganya, karena dia menjadi tulang punggung keluarga, dan ingin segera bisa menjadi manusia bebas seperti sebelum masuk Lapas. Untuk mengajukan PB, napi menghadap kepada Kasubsi Bimkemaswat kemudian diserahkan pada Wali Pemasyarakatan sebagai pendamping napi. Berbarengan dengan proses pemberkasan, Lapas mengirim surat kepada Bapas untuk pembuatan litmas oleh PK, sedangkan keluarga napi melengkapi administrasi seperti pas photo,materai dan surat-surat yang diperlukan sebagai persyaratan, yaitu surat dari Lurah atau Kepala Desa dan surat kesanggupan sebagai penjamin. Setelah pembuatan litmas PB dari Bapas selesai, berkas PB tersebut dimasukkan dalam agenda sidang TPP Lapas. Bila dalam sidang TPP Lapas semua persyaratan dipandang cukup, berkas tersebut dikirim ke Kanwil Kemkumham Bengkulu untuk dilakukan sidang TPP di tingkat Kanwil Kemkumham.Apabila dalam sidang TPP Kanwil Kemkumham lolos,berkas PB tersebut dikirim ke Jakarta ditujukan kepada Dirjen Pemasyarakatan untuk mendapatkan persetujuan kemudian Dirjen Pemasyarakatan atas nama Menteri akan menerbitkan SK PB. Pemohon PB berpendapat bahwa semua petugas tersebut membantu secara sukarela dan tidak meminta bayaran, tetapi secara ikhlas dan sukarela para napi memberikan sejumlah uang kepada Wali Pemasyarakatan sebagai ucapan terima kasih atas bantuan Wali Pemasyarakatan dalam pemberkasan. Mengenai jumlah uang yang diberikan, jawaban napi bermacam-macam, sekedar untuk makan dan minum Wali Pemasyarakatan selama pemberkasan sebesar Rp. 100.000,- sampai Rp.300.000,- sedangkan untuk pembuatan litmas mereka mengeluarkan uang Rp.300.000,- hingga Rp. 600.000,-. Menurut napi yang mengajukan $\mathrm{PB}$, proses pemberian $\mathrm{PB}$ danCB, sudah merata dan berkeadilan, karena semua napi yang telah memenuhi persyaratan berhak mengajukan. Menurut napi yang mengajukan PB, bila ada napi yang tidak bisa mengajukan PB karena kesalahan napi itu sendiri yaitu melakukan pelanggaran berat selama menjalani pidana atau tidak ada penjamin. Pada saat penelitian ini dilakukan, ada seorang informan pemohon $\mathrm{PB}, \mathrm{Nr}$, napi koruptor merasa resah karena terbentur dengan aturan baru yaitu Pasal 34A ayat (1) butir b dan Pasal 36A ayat (3) butir c PP No.99 Tahun 2012. Denda sebesar Rp.50.000.000,- telah dia penuhi, tetapi dengan adanya Pasal 36A ayat (3) butir c yang menyatakan bahwa pemohon PB harus menjalani asimilasi terlebih dulu untuk napi pidsus, akan menghambat proses PB yang ia ajukan. Pada saat wawancara ini dilakukan,aturan tentang asmilasi ini belum jelas bagaimana pelaksanaannya. PP No. 99 tahun 2012 ini berlaku mulai tanggal 12 November 2012, sementara $\mathrm{Nr}$ baru menjalani masa pidana penjaranya Desember 2012, tetapi putusan MA untuk perkaranya 
adalah tanggal 27 Juli 2011, oleh karena itu menurutnya dia tidak seharusnya terkena PP No. 99 Tahun 2012 ini. Nr telah mencoba mempertanyakan kepada petugas, apakah dia terkena aturan baru itu atau tidak, tetapi pada waktu itu tidak satupun pejabat di Lapas yang bisa memberi kepastian.

2) Informan kelompok napi yang mengajukan $\mathrm{CB}$, menyatakan, alasan pengajuan $\mathrm{CB}$ adalah: karena mengharapkan potongan masa pidana, ingin berkumpul dengan keluarga, ingin segera bebas dan bekerja lagi. Mereka menyampaikan keinginannya kepada petugas Lapas dan petugas merespon dengan baik, bahkan membantu dan mempermudah pengurusan syarat-syarat yang diperlukan. Petugas tidak meminta imbalan, tetapi napi memberi secara sukarela dengan alasan meskipun dia seorang napi, tetapimasih bisa berterima kasih pada orang yang telah menolong dirinya. Oleh karena itu bila dia memberikan uang sekedarnya adalah hal yang wajar dan tidak perlu dipersoalkan. Napi lainnya mengaku memberi uang sebesar Rp.200.000,- Menurut napi yang mengajukan $\mathrm{CB}$, pemberian $\mathrm{CB}$ pada napi sudah merata dan berkeadilan karena semua napi berhak mengajukannya. Dalam penelitian ini terungkap adanya jual beli sel oleh napi koruptor, seorang napi lain yangberstatus sebagai tampingmenyatakan bahwa sebelum pertengahan tahun 2012 para napi koruptor ditempatkan dalam sel tersendiri. Untuk menempati sel tersebut tarifnya sekitar Rp.1.500.000,sampai Rp.5.000.000,-, tetapi sejak akhir 2012 hingga tahun 2013 mulai tidak ada, napi koruptor sudah ditempatkan bersama napi lainnya hanya saja jumlah penghuninya lebih sedikit. Perubahan ini terjadi karena ada Kepala Lapas baru dan adanya program anti-halinar.

3) Informan kelompok napi yang tidak mengajukan $\mathrm{PB}$ dan $\mathrm{CB}$ menyatakan pada saat masuk Lapas diberi penjelasan mengenai hakhak dan kewajibannya dan memperoleh informasi mengenai PB, CMB dan CBdari petugas Lapas dan sesama napi. Mereka tidak mengajukan karena tidak memiliki penjamin dan tidak mempunyai uang. Mereka mendapat informasi dari napi lain,bahwa ada pungutan biaya pemberkasan di Lapas dan pengurusan litmas di Bapas, oleh karena itu mereka memutuskan akan menjalani saja masa pidananya hingga berakhir sesuai dengan ketentuan yang ada, meskipundalam hati kecilnya, sebenarnya ingin segera bebas..

4) Informan dari keluarga napiyang mengajukan $\mathrm{PB}$ dan $\mathrm{CB}$, menyatakan, bahwa harus tersedia dana Rp.600.000,- hingga Rp. 800.000,- untuk pemberkasan PB dan pembuatan litmas. Ada seorang informan yang tidak suka diwawancara panjang lebar, dengan singkat dia mengatakan bahwa di dunia ini tidak ada yang gratis, termasuk soal pengurusan PB. Dia menyatakan bahwa untuk pengurusan PB suaminya telah menyerahkan uang sebesar Rp. 500.000,- untuk Lapas, dan Rp.300.000,- kepada PK Bapas untuk pembuatan litmas

Pemberian sejumlah uang ini, dalam kajian Sosiologi Hukum, menjadi logis, karena ada berbagai situasi dan kepentingan yang 
menguntungkan bagi pemberi dan yang diberi, tetapi dari sudut padang normatif yuridis menjadi perbuatan melanggar hukum. Lebih-lebih bila dikaitkan dengan program anti-halinar, yang sedang gencar dilakukan di lingkungan Dirjen Pemasyarakatan Kemkumham. Harus diakuiprogram anti-halinar sudah berjalan baik dan sangat mengurangi penyimpangan yang terjadi di Lapas. Hal positif yang bisa dirasakan terutama bagi keluarga napi adalah tidak adanya pungutan ketika kunjungan ke Lapas. Pengurangan besarnya pungutan setelah program anti-halinar cukup besar. Ini terlihat ketikatim peneliti membandingkan dengan hasil penelitian kecil mahasiwa yang mengambil mata kuliah Bantuan Hukum dan Penyantunan Terpidana (BHPT) pada tahun 2011 sebelum adanya programanti-halinar. Pada tahun 2011 dana yang dikeluarkan napi sebesar Rp. 1.200.000,- hingga Rp. 1.500.000,-, dan bila melalui jalur khusus bias mencapai Rp.2.500.000,-. Setelah ada program anti-halinar, dana yang dikeluarkan adalah sekitar Rp.100.000,- hingga Rp.300.000,di tingkat Lapas, sedang di Bapas sekitar Rp. 300.000,- hingga Rp.600.000,-. Adanya program anti-halinar ini sudah memberikan perubahan pada pengurusan $\mathrm{PB}$ dan $\mathrm{CB}$, karena biaya yang dikeluarkan napi hanya di kisaran ratusan ribu saja.Agar program anti-halinar dan crash program bisa terus dilaksanakan,harus ada perubahan kebijakan dalam pengalokasian dana untuk pemberkasan $\mathrm{PB}, \mathrm{CMB}, \mathrm{CB}$ dan pembuatan litmas, serta pembedaan perlakuan pada napi pidum dan napi pidsus.Pembedaan perlakuan pada napi pidum dan napi pidsus dalam pengajuan $\mathrm{PB}, \mathrm{CMB}$ atau $\mathrm{CB}$ akan mengefektifkan program anti-halinar, mengurangi kelebihan kapasitas dalam Lapas dan akan mendukung tujuan Pemasyarakatan.

\section{Kendala-kendala Dalam PelaksanaanPembebasan Bersyarat (PB), CutiMenjelang Bebas (CMB) atau Cuti Bersyarat (CB) Pada Narapidana yang telah Memenuhi Persyaratan}

Temuan di lapangan tentang kendala dalam pelaksanaan PB, CMB atau $\mathrm{CB}$, yang bersumber dari informan, diuraikan di bawah ini :

1) Adanya perubahan aturan dalam hal pengajuan $\mathrm{PB}, \mathrm{CMB}$ ataupun $\mathrm{CB}$ bagi napi membingungkan napi dan petugas. Semula dasar hukum pemberian $\mathrm{PB}, \mathrm{CMB}$ dan $\mathrm{CB}$ adalah Pasal 5, 6 dan 7 Permenkumham No. M 01. PK.04. 10 tahun 2007 Jo.Permenkumham No. M.HH.01.PK.05.06 tahun 2008 tentang Perubahan Atas Permenkumham No. M 01. PK.04. 10 tahun 2007, kemudian diubah lagi dengan Permenkumham M.HH-02.PK.05.06 tahun 2010.Selanjutnya dengan diterbitkanPP No. 99 tahun 2012 dan Permenkumham Nomor 21 tahun 2013 sebagai peraturan pelaksanaannya, peraturan ini yang dipedomani, tetapi dalam pelaksanaannya menimbulkan permasalahan. Menurut Kadiv Pemasyarakatan Kanwil Kemkumham Provinsi Bengkulu PP No. 99 tahun 2012 dan Permenkumham Nomor 21 tahun 2013, dibuat 
tergesa-gesa, sehingga dalam penerapannya menimbulkan masalah. Salah satu permasalahannya adalah adanya peraturan yang keliru, misalnya Pasal 70Permenkumham No. 21 tahun 2013 bagi napi narkoba yang pidananya kurang dari 5 tahun seharusnya dipergunakan aturan untuk pidum. Artinya peraturan ini (pasal 70) salah sehingga dikeluarkan Surat Edaran, yang memberi pedoman bagaimana menafsirkan Pasal 70, ini tertuangdalam SuratDirjen Pemasyarakatan No. PAS.PK.01.05.06-184, tanggal 24 Juli 2013.

2) Keluarnya PP No. 99 tahun 2012, juga menimbulkan pro kontra apalagi yang terkena adalah napi pidsus (napi tindak pidana terorisme, narkotika dan prekusor narkotika \& psikotropika, napi korupsi, kejahatan terhadap keamanan negara, kejahatan HAM berat, serta kejahatan transnasional terorganisasi). Napi dengan tindak pidana ini adalah orang-orang yang bisa berpikir dan bisa menekan, kalau aturan pelaksanaannya tidak segera dibuat akan menimbulkan kebingungan dan keraguan petugas Lapas bagaimana cara mengusulkannya, sehingga muncul Permen No. 21 tahun 2013. Ternyata terbitnya Permen ini dalam penerapannya memunculkan permasalahan baru, terutama. untuk napi yang vonisnya jatuh sebelum tanggal 12 November 2013, apakah akan digunakan PP No. 99 tahun 2012 atau PP No. 28 tahun 2006. Untuk itu, dikeluarkan Surat Edaran Dirjen PemasyarakatanNo. PAS PK.01-01.02-162, tanggal 16 Juli 2013 yang menyatakan bagi napi yang vonisnya sebelum tanggal 12 November 2012 digunakan PP No. 28 Tahun 2006, sedangkan bagi napi yang putusannya setelah tanggal 12 November 2012 digunakan PP No. 99 tahun 2012. Dalam pelaksanaannya muncul persoalan dalam menafsirkan pelaksanaan putusan hakim, apakah berdasar pada tanggal putusan (vonis) hakim atau berdasar tanggal Berita Acara Pelaksanaan Putusan yang diterbitkan oleh Kejaksaan (BA 8). Kadiv Pemasyarakatan memberikan contohada duaputusan hakim yang diputuskan pada tanggal 11 November 2012, jaksa yang satu menerbitkan BA 8 pada tanggal12 November 2012, sedangkan jaksa yang lain, meskipun putusan hakimnya sama tanggal 11 November, menerbitkan BA 8 pada akhir bulan Januari 2013. Kalau yang dijadikan pedoman BA 8 , maka pada putusan hakim yang BA 8 nya terbit bulan Januari 2013 harus menggunakan PP No. 99 Tahun 2012, tentu saja ini akan merugikan napi. Oleh karena itu Kanwil Kemkumham Provinsi Bengkulu menafsirkan, bila antara tanggal putusan (vonis) hakim dengan BA 8 jaraknya terlalu jauh (dua bulan lebih), akan digunakan tanggal putusan hakim, atau bila perkaranya hingga kasasi, yang menjadi pedoman adalah tanggal putusan Mahkamah Agung (MA) sehingga tidak merugikan napi. Dalam kenyataannya banyak kasus yang antara tanggal vonis hakim dengan tanggal keluarnya BA 8 itu lama. Di Lapas Bengkulu, kondisi ini dialami oleh napi korupsi yang 
berinisial Nr. Perkara Nr ini hingga tingkat kasasi, putusan MA untuk perkara Nr pada tanggal 27 Juli 2011, tetapi baru dieksekusi jaksa atau BA 8 nya terbit pada tanggal 10 Desember 2012, sehingga ada keterlambatan 1 tahun 6 bulan. Awalnya menimbulkan kebingungan petugas Lapas dan napi itu sendiri, peraturan mana yang akan menjadi dasar PB, apakah PP No. 28 tahun 2006 atau PP No. 99 tahun 2012. Dengan penafsiran yang dipegang oleh Kanwil Kemkumham Provinsi Benglulu, peraturan yang diterapkan pada Nr adalah PP No. 28 tahun 2006, sehingga tidak merugikan $\mathrm{Nr}$.

3) Dengan berlakunya Permenkumham No. 21 tahun 2013, dasar hukum CB menjadi tidak ada, karena Permenkumham No. 21 tahun 2012 mencabut beberapa Permenkumham yang sebelumnya berlaku, diantaranya PermenkumhamNo. M.01.PK.04-10 tahun 2007. Dalam Permen tersebut mengatur dan mendefinisikan CB, sementara dalam Bab VIII Pasal 68 hingga 77 Permenkumham No. 21 tahun 2013 hanya mengatur syarat dan tata cara pemberian CB. Semestinya dalam Bab I Pasal 1, dicantumkan pengertian CB. Mungkin dalam praktek pelaksanaan CB tidak menjadi masalah, tetapi secara teoritis, terutama bagi dunia akademik akan muncul pertanyaan, rumusan atau pengertian atau CB tidak ada, tetapi tibatiba muncul syarat dan tata cara pengajuan $\mathrm{CB}$. Ini berbeda dengan PB dan CMB, dalam penjelasan Pasal 14 huruf $\mathrm{k}$ dan huruf IUU No. 12 tahun 1995 memberikan pengertian atau definisiPB dan CMB, demikian juga dalam Pasal 1 butir 7 PP No. 32 tahun 1999, dicantumkan pengertian atau definisi PB. Hal ini menunjukkan bahwa ada kekurangtelitian dalam pembuatan Permenkumham No. 21 tahun 2013. Semestinya dalam Bab XIX Pasal 96, ditambahkan "dicabut dan dinyatakan tidak berlaku sepanjang telah diatur dalam peraturan ini" (artinya sepanjang telah diatur dalam Permenkumham No. 21 tahun 2013, isi Permenkumham yang sudah dicabut,tetapi tidak diatur dalam Permenkumham No. 21 tahun 2013tetap berlaku, khususnya untuk rumusan atau definisi $\mathrm{CB})$.

4) Pada saat penelitian ini dilakukan belum ada format baku surat keterangan dari Kejaksaan tentang kesediaan menjadi justice collaborator berdasar PP No. 21 tahun 2013 Jo. Permenkemkumham No. 21 tahun 2013. Menurut beberapa informan baik dari napi koruptor maupun petugas di Lapas dan Bapas, surat keterangan tersebut akan menimbulkan peluang untuk disalahgunakan. Isu yang berkembang untuk mendapatkan surat keterangan ini, para napi koruptor harus mengeluarkan uang antara Rp.1.000.000,- hingga Rp.2.500.000,-

5) Birokrasi di Kejaksaan Negeri dalam hal penerbitan surat keterangan bahwa napi yang akan mengajukan PB, CMB ataupun $\mathrm{CB}$ tidak sedang terlibat dalam perkara lain, sering terlambat dan 
memakan waktu cukup panjang. Ini telah teratasi dengan cara bila dalam waktu 14 hari surat keterangan dari Kejaksaan tidak diterbitkan, Lapas akan tetap meneruskan berkas PB, CMB atau CB dengan melampirkan surat permintaan dari Lapas kepada Kejaksaan Negeri tentang daftar nama napi yang memerlukan surat keterangan tidak ada perkara lainnya. Meskipun sudah teratasi, kondisiini menunjukkan tidak ada koordinasi yang baik antara Kejaksaan dan Lapas, serta terkesan Kejaksaan menyepelekan persyaratan ini, padahal surat keterangan ini sangat diperlukan sebagai salah satu persyaratan supaya napi memperoleh dan menikmati haknya. Demikan jugaketerlambatan penerbitan BA 8, sangat merugikan napi.

6) Kendala bagi napi yang tidak bisa mengajukan $\mathrm{PB}, \mathrm{CMB}$ dan $\mathrm{CB}$ adalah tidak ada penjamin dan tidak mempunyai uang, meskipun persyaratan lainnya sudah lengkap.

7) Kurangnya sarana dan prasarana. Di Lapas Bengkulu berupa laptop dan kertas untuk pemberkasan, serta meja kerja. Di Bapas Bengkulu dibutuhkan komputer untuk penyusunan litmas, karena di bagian Bimbingan Klien Dewasa (BKD) hanya satu buah komputer, demikian juga di bagian Bimbingan Klien Anak (BKA), hanya ada sebuah komputer, dari dua komputer tersebut salah satunya sudahrusak. Kendaraan operasional untuk mencari data lapangan yang dimiliki Bapas hanya sebuah kendaraan bermotor roda dua, belum ada tustel ataupun alat perekam sebagai alat penunjang dalam pengumpulan data lapangan.

8) Tidak semua Wali Pemasyarakatan menghadiri persidangan TPP Lapas, sehingga kadangkala usul dan pendapatnya yang cukup penting tidak terakomodir.

9) Keterlambatan litmas yang dibuat oleh Bapas Bengkulu. Penyebabnya menurut PK Bapas adalah lambatnya pengurusan surat jaminan dari keluarga dan surat keterangan dari kelurahan atau desa setempat, sehingga mempengaruhi selesainya pembuatan litmas.

10) Proses pengusulan sampai diterbitkan Surat Keputusan PB, CMB dan $\mathrm{CB}$ relatif lama, terutama untuk $\mathrm{PB}$, karena harus dikirim ke Dirjen Pemasyarakatan Kemkumham di Jakarta. Untuk penerbitan SK CMB dan CB rata-rata antara satu hingga dua bulan, sedangkan untuk PB memerlukan waktu tiga hingga enam bulan.

11) Persidangan TPP Lapas kadang kala tidak tepat waktu dan tidak lengkap, karena kesibukan anggota TPP yang berbeda-beda. 


\section{Susunan Draft Model Sistem Pembinaan Luar Lembaga Bagi Narapidana Dalam Pelaksanaan PB, CMB dan CB yang Merata dan Berkeadilan Berperspektif pada Tujuan Pemasyarakatan}

Pelaksanaan PB, CMB atau CB masih belum bebas total dari pungli, meskipun pemberian uang pada petugas diinterpetasikan oleh napi sebagai ucapan terima kasih dan jumlahnya relatif kecil. Pihak Lapas dan Bapas menyatakan tidak ada pungutan, tetapi atas terbatasnya biaya pemberkasan, pihak Lapas dan Bapas membuka peluang adanya pemberian dari napi, dengan menyatakan "kalau diberi diterima, tetapi petugas dilarang meminta", mengaburkan tekad pelaksanaan program anti-halinar. Tidak mudah untuk mengubah kebiasaan ini, oleh karena itu diperlukan cara memperkecil peluang terjadinya pungli. Untuk itu diperlukan model pelaksanaan $\mathrm{PB}, \mathrm{CMB}$ atau $\mathrm{CB}$ yang bisa memberikan keadilan dan pemerataan bagi semua napi. Model ini penting untuk mendukung terwujudnya tujuan Pemasyarakatan yang merata dan berkeadilan dan akan menjamin efektifitas pelaksanaan program antihalinar. Tim peneliti menawarkan model sebagai berikut:

1) Pembedaan Konsep Model pelaksanaan PB bagi napi tindak pidana umum (pidum) dan napi pengguna narkoba yang hukumannya di bawah 5 tahun dengan tindak pidana khusus (pidsus).

2) Pembedaan Model pelaksanaan CB untuk napi tindak pidana umum (pidum) dan pengguna narkotika yang sanksi pidananya di bawah 5 tahun dengan tindak pidana khusus (pidsus).

3) Konsep Model Sistem Pembinaan Luar Lembaga Bagi Narapidana yang Merata dan Berkeadilan Berperspektif pada Tujuan Pemasyarakatan. 


\section{Bagan 1}

Konsep Model Sistem Pelaksanaan PB yang Merata \& Berkeadilan Berperspektif pada Tujuan Pemasyarakatan

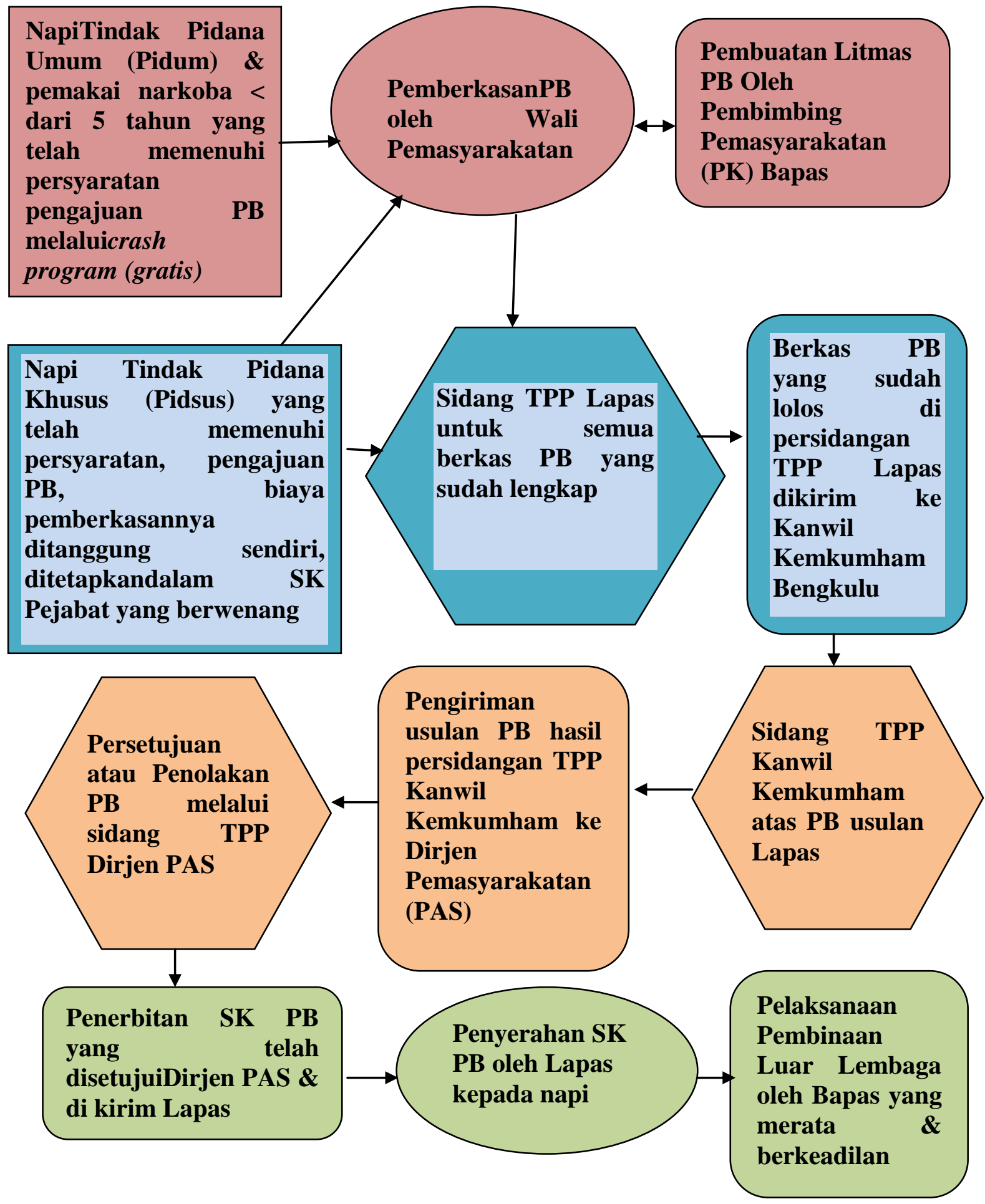

Sumber: Disusun Tim Peneliti 


\section{Bagan 2}

Konsep Model Sistem Pelaksanaan CB Yang Merata \& Berkeadilan

Berperspektif Pada Tujuan Pemasyarakatan

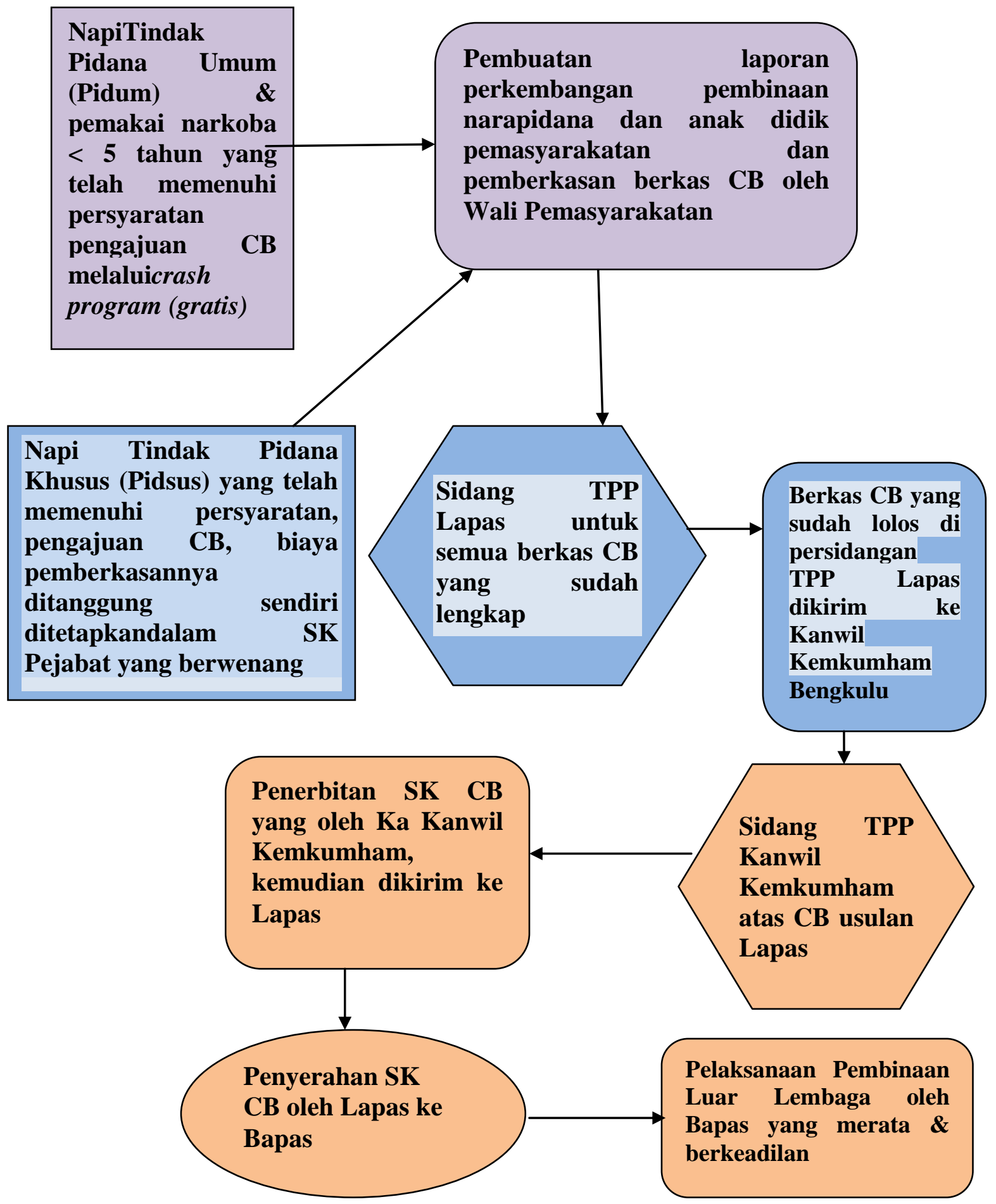

Sumber : Disusun Tim Peneliti 
Pada saat model ini didiskusikan dengan Kadiv Pemasyarakatan Kanwil Kemkumham Provinsi Bengkulu, mereka tidak sependapat mengenai biaya yang harus ditanggung oleh napi pidsus yang akan mengajukan $\mathrm{PB}, \mathrm{CMB}$ atau $\mathrm{CB}$. Alasannya $\mathrm{PB}, \mathrm{CMB}$ dan $\mathrm{CB}$ harus diberikan tanpa pungutan sama sekali, karena pelayanan di Lapas adalah layanan publik dan KPK tidak mengijinkan adanya penarikan uang.Kekurangan dana untuk pemberkasan $\mathrm{PB}, \mathrm{CMB}$ dan $\mathrm{CB}$, menjadi tanggung jawab Kepala Lapas untuk kreatif menutup kekurangan tersebut. Sebagai contoh, bila dana pemberkasan PB, CMB atau CB tidak mencukupi, harus dilakukan revisi anggaran. Caranya, anggaran yangbelum terlalu penting seperti biaya pemeliharaan (mengecat ulang gedung, anggaran ATK dan yang lainnya), bisa dialihkan untuk pemberkasan PB, CMB atau CB. Menurut Kadiv Pemasyarakatan, lebih berbahaya menarik atau mengambil uang dari napi koruptor daripada meminta dari napi pencuri. Kalau minta dari napi mantan kepala Dinas yang koruptor, maka dia akan menceritakan kemana-mana tentang penarikan uang di Lapas, tetapi kalau napi pencuri, selesai dimintai uang, selesai perkaranya. Demikian pula mengenai tes urine pada napi narkoba yang mengajukan $\mathrm{PB}, \mathrm{CMB}$ atau $\mathrm{CB}$, bukan merupakan syarat yang ditentukan oleh undang-undang. Diakui oleh Kadiv Pemasyarakatan, bahwa tes urine ini baik, oleh karena itu cukup diambil sampelnya saja dan biaya sepenuhnya ditanggung oleh Lapas.

Perbedaan cara pandang antara Kadiv Pemasyarakatan dengan tim peneliti mengenai pelaksanaan $\mathrm{PB}, \mathrm{CMB}$ atau $\mathrm{CB}$ secara ilmiah merupakan hal yang wajar. Kadiv Pemasyarakatan Kemkumham Provinsi Bengkulu bertitik tolak dari sudut pandang normatif yuridis dan asas kepastian hukum, sedangkan tim peneliti berangkat dari sudut pandang yuridis empiris (Sosiologi Hukum). Bila didukung dana yang memadai tentu sudut pandang normatif yuridis menjadi pilihan yang terbaik dan harus dilaksanakan, tetapi pelaksanaan hukum juga harus mempertimbangkan aspek sosiologis atau kemanfaatan hukum. Realitas menunjukkan dana pemberkasan memang tidak mencukupi dan pungli dalam skala kecil tetap ada, oleh karena itu perlu ada konsep yang berbentuk pembedaan bagi napi pidsus dan napi pidum dalam pengajuan dan pengurusan $\mathrm{PB}, \mathrm{CMB}$ atau $\mathrm{CB}$.Untuk napi pidum dan napi narkoba yang pidananya kurang dari 5 tahun semua beban biaya pengajuan dan pengurusan $\mathrm{PB}, \mathrm{CMB}$ atau $\mathrm{CB}$ ditanggung oleh Pemerintah dengan mengacu pada model crash program, yang telah terlaksana pada bulan Juni 2013. Untuk napi pidsus harus menanggung sendiri semua biaya pemberkasan hingga pengiriman. Biaya itu harus transparan, oleh karena itu harus dituangkan dalam bentuk Surat Keputusan dari pejabat yang berwenang (Dirjen Pemasyarakatan atau pejabat Kanwil Kemkumham). Adanya pembedaan ini akan berdampak: program $\mathrm{PB}, \mathrm{CMB}, \mathrm{CB}$ akan merata dan berkeadilan, karena napi yang miskin tetap bisa menikmati $\mathrm{PB}, \mathrm{CMB}$ atau $\mathrm{CB}$ seperti napi lainnya, mengurangi kelebihan kapasitas 
penghuni Lapas dan program anti-halinar, terutama untuk pengurangan atau pemberantasan pungli bisa terlaksana secara penuh.

Setelah Surat Keputusan PB, CMB atau CB keluar, pembinaan pada napi harus dilanjutkan dalam bentuk pembinaan luar lembaga dan status napi sudah berubah menjadi klien pemasyarakatan. Di bawah ini ditawarkan konsep model pembinaan luar lembaga yang disusun oleh tim peneliti, sebagai berikut: 


\section{Bagan 3 \\ KONSEP MODEL SISTEM PEMBINAAN LUAR LEMBAGA BAGI NARAPIDANAYANG MERATA \& BERKEADILAN BERPERSPEKTIF PADA TUJUAN PEMASYARAKATAN}

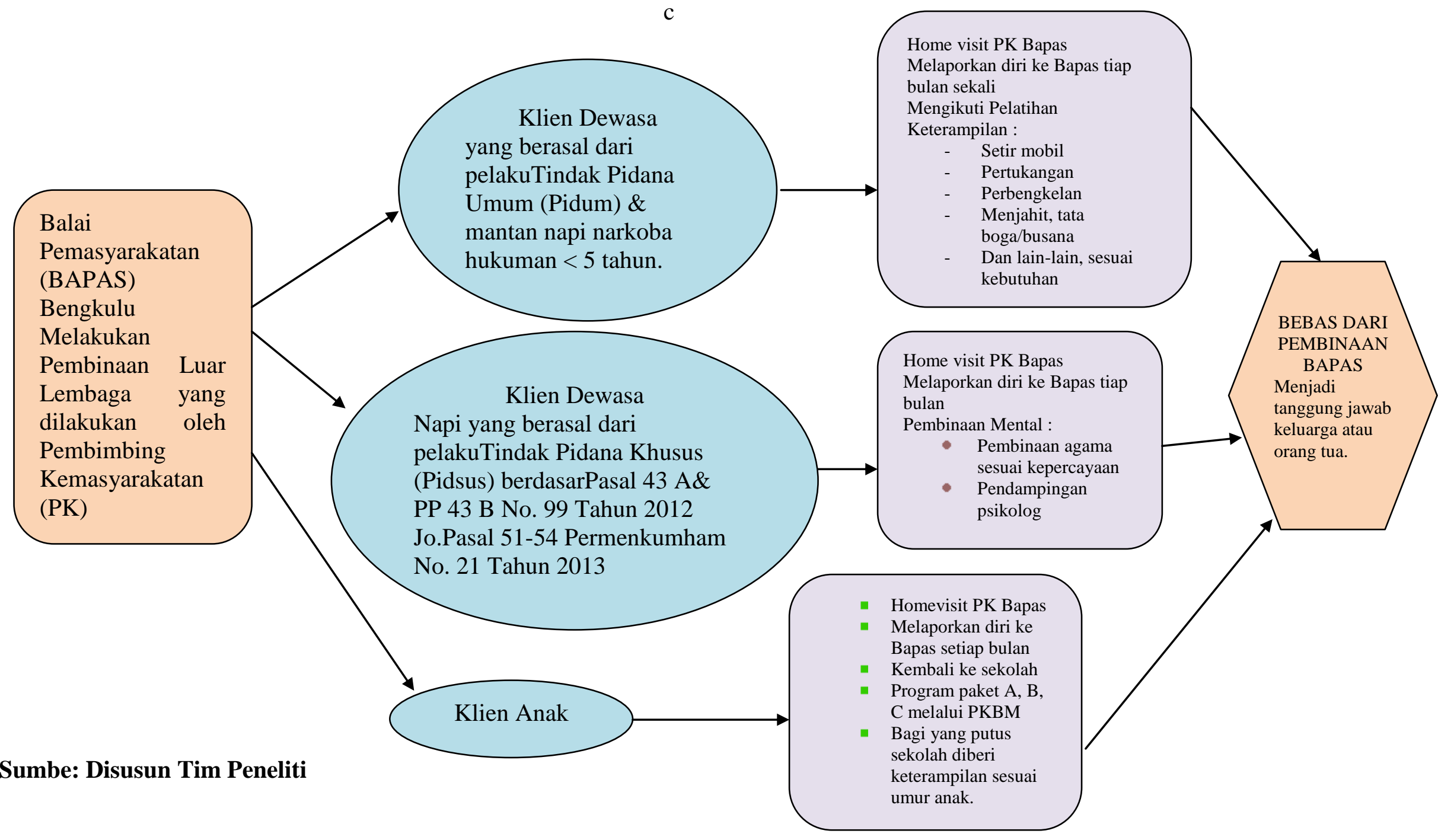


Alasan tim peneliti mengemukakan model ini adalah pembinaan luar lembaga di Bapas yang selama ini sudah berjalan hanya berbentuk kewajiban klien pemasyarakatan melaporkan diri pada Bapas setiap bulan.Hanya ada satu atau dua jenis pembinaan keterampilan yang ditujukan kepada sebagian kecil klien pemasyarakatan, (untuk 30-40 orang) karena dananya terbatas. Pada tahun 2013 Bapas Bengkulu, melaksanakan pembinaan keterampilan berupa setir mobildan pertukangan, hanya untuk 30 orang klien pemasyarakatan.Akibatnya tidak semua klien pemasyarakatan memperoleh pembinaan keterampilan. Disamping danayang terbatas, juga karena setiap tahunnya belum tentu ada pembinaan keterampilan untuk klien pemasyarakatan yang didanai oleh Dirjen Pemasyarakatan ataupun belum tentu ada kerja sama antara Bapasdengan institusi lain seperti dengan Balai Latihan Kerja (BLK) atau Dinas Sosial.

Idealnya pembinaan luar lembaga ini sasarannya adalah seluruh klien pemasyarakatan dan sesuai dengan kebutuhan mereka. Oleh karena itu konsep model pembinaan luar lembaga yang dikemukakan tim peneliti dalam bagan 3 menggambarkan:

1) Adanya pembedaan pembinaan bagi klien pemasyarakatan yang berasal dari napi pidum, napi pidsus dan anak didik pemasyarakatan.

2) Pembinaan luar lembaga yang dilakukan Bapas harus mengakomodir kebutuhan klien pemasyarakatan, karena untuk napi pidum dan napi pidsus kebutuhannnya berbeda. Pada napi pidum bentuk pembinaan yang perlu adalah pemberian keterampilan yang bisa digunakan untuk mata pencaharian, seperti setir mobil, pertukangan, perbengkelan, menjahit dan tata boga/tata busana. Pembinaan seperti ini tentu tidak menjadi kebutuhan napi pidsus karena napi pidsus lebih memerlukan pendampingan psikologis, pembinaan mental dan spiritual serta konsultasi psikologi. Pada anak yang menjadi klien pemasyarakatan, pembinaan harus ditekankan untuk mendorong anak kembali bersekolah, bagi anak yang tidak mampu PK Bapas harus bekerja sama dengan Pusat Kegiatan Belajar Masyarakat (PKBM), sehingga anak bisa mengikuti program paket $\mathrm{A}, \mathrm{B}$, atau $\mathrm{C}$, sesuai kebutuhan anak. Pendidikan ini penting diberikan untuk memenuhi amanat UU No. 23 Tahun 2002 tentang Perlindungan Anak yang mewajibkan pendidikan 9 tahun pada anak (setingkat SMP).

3) Home visit wajib dilakukan oleh PK Bapas secara rutin pada setiap klien pemasyarakatan. Dalam kunjungan ini PK Bapas mempersiapkan mental klien pemasyarakatan supaya mereka mampu kembali ke tengah-tengah masyarakat, menjadi orang yang benar-benar bebas dan mampu bertanggung jawab. Bila semua ini bisa dilaksanakan, maka sistem pembinaan luar lembaga bagi napi 
yang merata dan berkeadilan berperspektif pada tujuan Pemasyarakatan akan terwujud.

\section{Penutup}

\section{Kesimpulan}

1. Menurut napi yang mengajukan, proses pelaksanaan $\mathrm{PB}, \mathrm{CMB}$ atau CB sudah berjalan dengan baik, merata dan berkeadilan. Pada napi yang tidak mengajukan $\mathrm{PB}, \mathrm{CMB}, \mathrm{CB}$ berpendapat sebaliknya. Menurut kelompok petugas di Lapas, Bapas dan Kanwil Kemkumham pengurusan PB, CMB atau CB sudah berjalan dengan baik dan tidak ada pungutan biaya apapun. Kelompoknapi menyebutkanada dana yang harus dikeluarkan napi sebesar Rp.100.000,- hingga Rp.300.000,- untuk biaya pemberkasan dan untuk litmas sebesar Rp.300.000,- hingga Rp.600.000,-. Kelompok napi menyebutkan dana yang dikeluarkan ini berdasar kerelaan hati mereka dan hanya sebagai ungkapan rasa terima kasih kepada petugas. Dana pemberkasan yang tersedia dalam DIPA tidak mencukupi, sehingga menurut penafsiran napi dan petugas pemberian ini masih wajar dan tidak dikategorikan pungli. Untuk napi narkoba yang mengajukan PB atau $\mathrm{CB}$ harus melalukan tes urine, napi bebas melakukan tes urine ini di mana saja, tetapi kalau memilih dilakukan di Lapas maka akan dikenai dana sebesar Rp.100.000,- Napi yang tidak mengusulkan menyatakan, mereka tidak mengusulkan PB, CMB atau $\mathrm{CB}$ karena tidak punya penjamin dan tidak punya uang. Di jajaran Direktorat Jenderal Pemasyarakatan ada program antihalinar. Dengan adanya program ini pungli di Lapas Bengkulu pada tahun 2013 ini sudah sangat jauh berkurang bila dibandingkan dengan tahun 2011. Untuk larangan pengunaan handphone belum sepenuhnya terlaksana, karena napi masih bebas menggunakan handphone, kecuali ada razia. Peran Wali Pemasyarakatan masih terbatas, hanya mendampingi napi ketika akan mengurusi $\mathrm{PB}, \mathrm{CMB}$ atau $\mathrm{CB}$.

2. Hambatan yang terjadi terkait pelaksanaan $\mathrm{PB}, \mathrm{CMB}$ dan $\mathrm{CB}$ adalah pada tahun 2012 hingga 2013 sering ada perubahan aturan, sehingga membingungkan petugas dan napi. Penerbitan surat keterangan bahwa napi tidak sedang ada perkara lain oleh Kejaksaan sering terlambat. Hambatan lain, bagi napi yang tidak mengajukan $\mathrm{PB}, \mathrm{CMB}$ atau $\mathrm{CB}$ adalah masalah penjamin dan tidak memiliki uang untuk pengurusannya, sarana dan prasarana di Lapas dan Bapas terbatas, terutama komputer dan kendaraan bagi PK Bapas. Ada keterlambatan dalam pembuatan litmas dan proses penerbitan Surat Keputusan PB. Program anti-halinar belum berjalan efektif karena masih banyak napi yang harus 
mengeluarkan sejumlah uang untuk pengurusan $\mathrm{PB}, \mathrm{CMB}$ atau CB.

3. Tim peneliti mengajukan pembedaan konsep model pelaksanaan $\mathrm{PB}, \mathrm{CMB}$ atau $\mathrm{CB}$, bagi napi pidsus dan napi pidum,supaya $\mathrm{PB}$, $\mathrm{CMB}$ atau $\mathrm{CB}$ merata dan berkeadilan dan dapat dinikmati oleh semua napi yang berhak. Pelaksanaan PB, CMB atau CB untuk napi pidum digratiskan seperti model crash program yang dilaksanakan pada bulan Juni 2013, sedang napi pidsus dikenai biaya yang ditetapkan oleh pejabat yang berwenang. Menurut tim peneliti bila model ini dilaksanakan akan mengefektifkan program anti- halinar, mengurangi kelebihan kapasitas dalam Lapas dan mendukung tujuan Pemasyarakatan. Menurut tim peneliti perludilegalkan saja biaya pemberkasan $\mathrm{PB}, \mathrm{CMB}$ dan $\mathrm{CB}$ bagi napi pidsus, ketimbang dilakukan secara sembunyi-sembunyi supaya tidak menghambat program anti-halinar, tetapi Kanwil Kemkumham Provinsi Bengkulu tidak sependapat PB, CMB atau $\mathrm{CB}$ harus gratis bagi semua napi tanpa ada pembedaan. Tim peneliti berpendapat, pembinaan luar lembaga bagi napi yang telah menjalani $\mathrm{PB}, \mathrm{CMB}$ atau $\mathrm{CB}$ oleh Bapas harus bertumpu pada pembinaan keterampilan bagi napi pidum dan bagi napi pidsus lebih dititik beratkan pembinaan mental spiritual, sedangkan pada anak harus didorong untuk kembali ke sekolah.

\section{Saran}

1. Peran Wali Pemasyarakatan harus ditingkatkan, mereka harus mendampingi napi sejak menjalani pidana di Lapas, hingga napi selesai menjalani pidananya dan diperlukan pelatihan khusus bagi Wali Pemasyarakatan supaya pembinaan pada napi selama di Lapas menjadi efektif dan berdaya guna.

2. Supaya program anti-halinar bisa berjalan dengan baik perlu peningkatan atau penambahan dana pemberkasan dalam DIPA. Pilihan kedua, konsep model yang diajukan peneliti, dipertimbangkan untuk dilaksanakan. Pemberian dari napi kepada petugas atau pungutan tidak resmi akan terus berlangsung sepanjang dana DIPA yang dialokasikan untuk pemberkasan tidak mencukupi.

3. Perlu ada revisi, karena PP No. 99 tahun 2012 Jo. Permenkemkumham No.21 tahun 2013, terutama tentang justice collaborator, kalau realisasinya hanya selembar surat keterangan saja dari institusi penegak hukum lainnya menjadi tidak penting, karena hanya akan menghambat pelaksanaan remisi, asimilasi, PB, CMB atau CB dan menambah beban kerja petugas Lapas.

4. Sistem Informasi Pemasyarakatan harus segera diwujudkan, karena adanya Sistem Informasi Pemasyarakatan, biaya pemberkasan $\mathrm{PB}, \mathrm{CMB}$ atau $\mathrm{CB}$ akan lebih murah. 
5. Pembinaan keterampilan bagi napi pidum di Lapasharus ditingkatkan jenis dan volumenya, kemudian dilanjutkan oleh Bapas bila mereka telah berstatus sebagai klien pemasyarakatan, sehingga mereka memiliki keterampilan yang bisa dijadikan bekal untuk mata pencaharian mereka.

6. Pembinaan mental spiritual dan pendampingan psikologis perlu diberikan pada napi pidsus, supaya menyadari kesalahannya dan bertobat. Ini penting dilakukan karena dari hasil penelitian mahasiswa tidak ada napi koruptor yang merasa bersalah dan mengakui kesalahannya.

7. Peranan dan fungsi Bapas harus ditingkatkan, program pembinaan keterampilan bagi napi pidum harus diperbanyak, supaya mereka mempunyai bekal untuk memperoleh mata pencaharian. 


\section{Daftar Pustaka}

\section{Buku}

Dirdjosisworo, Soedjono. Kriminologi Ruang Lingkup Dan Cara Penelitian, Bandung: Tarsito 1974.

Bandung: Armico, 1984.

Direktorat Jenderal Pemasyarakatan, Departemen Kehakiman dan Hak Asasi Manusia RI. 40 Tahun Pemasyarakatan: Mengukur Citra Profesionalisme, Jakarta, Depkeh HAM, 2004.

Febrianti, Rizky dkk., Tugas Mata kuliah BHPT tentang Pelaksanaan PB, CMB dan CB di Lapas Bengkulu, Fakultas Hukum UNIB Tahun 2011.

Gunakarya, A. Widia. Sejarah dan Konsepsi Pemasyarakatan, Bandung: Armico 1988.

Hartati, Poppy. Pelaksanaan Pembebasan Bersyarat, Cuti Menjelang Bebas, Cuti Bersyarat Bagi Narapidana Di Bengkulu, Skripsi, pada Fakultas Hukum Universitas Bengkulu, 2009.

Moleong, Lexy. Metodologi Penelitian Kualitatif, Bandung: Remaja Rosdakarya, 2006.

Muladi \& Nawawi Arief, Barda. Teori-teori dan Kebijakan Pidana, Bandung: Alumni 1992.

Ochta W. Amelia. Pelaksanaan Tahap Integrasi Di Lapas Bengkulu, Tugas Mata Kuliah BHPT, Fakultas Hukum UNIB Tahun 2010.

Soegondo, HR. Prinsip-prinsip Konsepsi Pemasyarakatan Hasil Konperensi Lembang 1964 Serta Pengembangannya Dewasa In, makalah, disampaikan pada SARPENAS 11 IKA-AKIP, Departemen Kehakiman RI, Lembang Bandung, 27 April 1994.

Soerkanto, Soerjono. Pokok-pokok Sosiologi Hukum, Jakarta: Rajawali Press, 1988.

HILL-CO, 1990.

\section{Peraturan- peraturan}

Undang-undang No. 12 Tahun 1995 tentang Pemasyarakatan.

Keputusan Menteri Kehakiman Republik Indonesia No. M.01.PK.04-10 Tahun 1999, tentang Asimilasi, Pembebasan Bersyarat dan Cuti Menjelang Bebas. 
Peraturan Pemerintah No. 31 Tahun 1999 tentang Pembinaan dan Pembimbingan Warga Binaan Pemasyarakatan.

Peraturan Pemerintah No. 32Tahun 1999 tentang Syarat dan Tata Cara Pelaksanaan Hak Warga Binaan Pemasyarakatan

Peraturan Pemerintah No. 28 Tahun 2006 tentang Perubahan Atas Peraturan Pemerintah No. 32 Tahun 1999 tentang Syarat dan Tata Cara Pelaksanaan Hak Warga Binaan Pemasyarakatan.

Peraturan Pemerintah No. 99 Tahun 2012 tentang Perubahan Kedua Atas Peraturan Pemerintah No. 32 Tahun 1999 tentang Syarat dan Tata Cara Pelaksanaan Hak Warga Binaan Pemasyarakatan

Peraturan Menteri Hukum dan Hak Asasi Manusia Republik Indonesia No. M.01. PK.04-10 Tahun 2007 tentang Syarat dan Tata Cara Pelaksanaan Asimilasi, Pembebasan Bersyarat, Cuti Menjelang Bebas dan Cuti Bersyarat.

Peraturan Menteri Hukum dan Hak Asasi Manusia Republik Indonesia No. M.02.PK.04.10. tentang Wali Pemasyarakatan.

Peraturan Menteri Hukum dan Hak asasi Manusia Republik Indonesia No. M.HH.07.KP.05.02 Tahun 2012 tentang Kode Etik Pegawai Negeri Sipil Di Lingkungan Kementerian Hukum dan Hak Asasi Manusia.

Peraturan Menteri Hukum dan Ham No. 6 Tahun 2013 tentang Tata Tertib Lembaga Pemasyarakatan dan Rumah Tahanan Negara

Peraturan Menteri Hukum dan Hak Asasi Manusia Republik IndonesiaNo. 21 Tahun 2013 tentang Syarat dan Tata Cara Pemberian Remisi, Asimilasi, Cuti Mengunjungi Keluarga, Pembebasan Bersyarat, Cuti Menjelang Bebas dan Cuti Bersyarat.

Surat Direktorat Jenderal Pemasyarakatan Kementerian Hukum dan Hak Asasi Manusia Republik Indonesia No. PAS. PK.01.05.06-124, 24 Mei 2013 perihal Crash Program dalam rangka pengendalian isi hunian.

Surat Direktorat Jenderal Pemasyarakatan Kementerian Hukum dan Hak Asasi Manusia Republik Indonesia No. PAS.PK.01.05.06-184, 24 Juli 2013,perihal Pelaksanaan Cuti Bersyarat Narapidana Tindak Pidana Narkotika, Prekusor Narkotika dan psikotropika Sebagaimana diatur dalam Pasal 70 ayat (1) Peraturan Menteri No. 21 Tahun 2013.

\section{Klipping}

"Mengantar Maut di Lembaga Pemasyarakatan", Harian Kompas, 21 April 2007 ,

"Perbaikan Nasib Napi Terintegrasi", Harian Kompas, 19 Mei 2007.

”LP Kelebihan Penghuni 55.000 Orang”, Harian Kompas, 18 Juli 2010. 
“Murahnya” Pembebasan Bersyarat, Harian Kompas", 7 Maret 2012.

"Keputusan Menteri Salah, Pembebasan Bersyarat untuk Terpidana Korupsi 2", Harian Kompas, 8 Maret 2012.

"Putusan PTUN Enam Narapidana Korupsi Bebas, Satu Orang Tetap Memilih Ditahan Karena Akan Bebas Murni Pada April 2012”, Harian Kompas, 10 Maret 2012.

"Ada “Bom Waktu” di Penjara”, Harian Kompas, 13 Juli, 2013.

"Lembaga Pemasyarakatan, Manajemen "Doa: di Penjara", Harian Kompas, 16 Juli 2013, 